Reprod. Nutr. Dévelop., 1985, 25 (5), 963-976.

\title{
Biochemical modifications involved in the maturation of the ovine fetal adrenal gland in late gestation : their modalities and regulation.
}

\author{
Ph. DURAND, Anne-Marie CATHIARD (*), A. LOCATELLI, J. M. SAEZ (*) \\ Station de Physiologie de la Reproduction I.N.R.A. \\ Nouzilly 37380 Monnaie, France. \\ (*) I.N.S.E.R.M. U162, Hôpital Debrousse 62332 Lyon cedex 05, France.
}

\begin{abstract}
Summary. During the last month of intra-uterine life, the steroidogenic response of the ovine fetal adrenal glands to ACTH increases and becomes maximal at the time of birth. This development involves modifications at different steps of the adrenocorticotropic hormone $(\mathrm{ATCH})$ action mechanism. It has been shown that the enhanced capacity of the cells to produce CAMP is related to at least three factors : an increased number of ACTH receptors, increased activity of the Ns subunit of adenylate cyclase, and enhancement of guanosine 5 -triphosphate (GTP) availability. The ability to produce pregnelone and the activity of both $3 \beta$-hydroxy steroid dehydrogenase/isomerase and $17 \alpha$-hydroxylase are mainly enhanced in the steroidogenic pathway. The infusion of ACTH for 5 days into 115 to 120-day old fetuses results in the development of most of these biochemical process. Similarly, ACTH can induce maturation of cultured fetal adrenal cells and some other proopiomelamocortin (POMC)-derived peptides can potentiate its acute steroidogenic activity in vitro. However, even in the absence of ACTH, the adenylate cyclase system and the steroidogenic potency of cultured cells increase but to a lesser extent than when ACTH is present in the culture medium. It is suggested that ACTH is the main trophic hormone of the ovine fetal adrenal during the last month of gestation, even if other stimulatory factors may also be important. The in vivo maturation of ovine fetal adrenal is blocked by the presence of some unknown inhibitory factors in the fetal circulation which are of likely extrapituitary origin.
\end{abstract}

\section{Introduction}

During the last 3 weeks of intrauterine life, the weight of the ovine fetal adrenals increases strikingly (Comline and Silver, 1961). This results mainly from the growth of the cortical zona and expresses both cellular hyperplasia and hypertrophy (Durand et al., 1978; Robinson et al., 1979). The steroidogenic response of fetal adrenal glands to adrenocorticotropic hormone (ACTH) develops simultaneously (Basset and Thorburn, 1973 ; Madill and Basset, 1973 ; Wintour et al., 1975) and becomes maximal at the time of delivery. In this survey, attention will be focused on results from our laboratories regarding the biochemical steps involved in the enhancement of ovine fetal adrenal cell responsiveness to ACTH between 115 to 120 days of gestation and birth (145 \pm 1 day in our experiments). 
Moreover, since ACTH infused into the ovine fetus for several days is able to make the adrenal cells responsive to this hormone, at a time when they are normally unresponsive (Liggins, 1968), we can report the effect of such a treatment on the enzyme activities we have studied during spontaneous maturation. Finally, recent data on the in vitro effects of proopiomelanocortin (POMC)-derived peptides or of pituitary extracts and of fetal hypophysectomy on the ability of fetal adrenal cells to produce both cAMP and corticosteroids in vitro are presented.

\section{Development of the ACTH-receptor adenylate cyclase system.}

The number of ACTH receptors and the adenylate cyclase (AC) activity of adrenal crude membranes from ovine fetuses and newborn lambs is shown in figure 1. The number of ACTH binding sites remains low until 140 days of gestation and increases 3 -fold during the last 5 days of gestation. At 124 days,
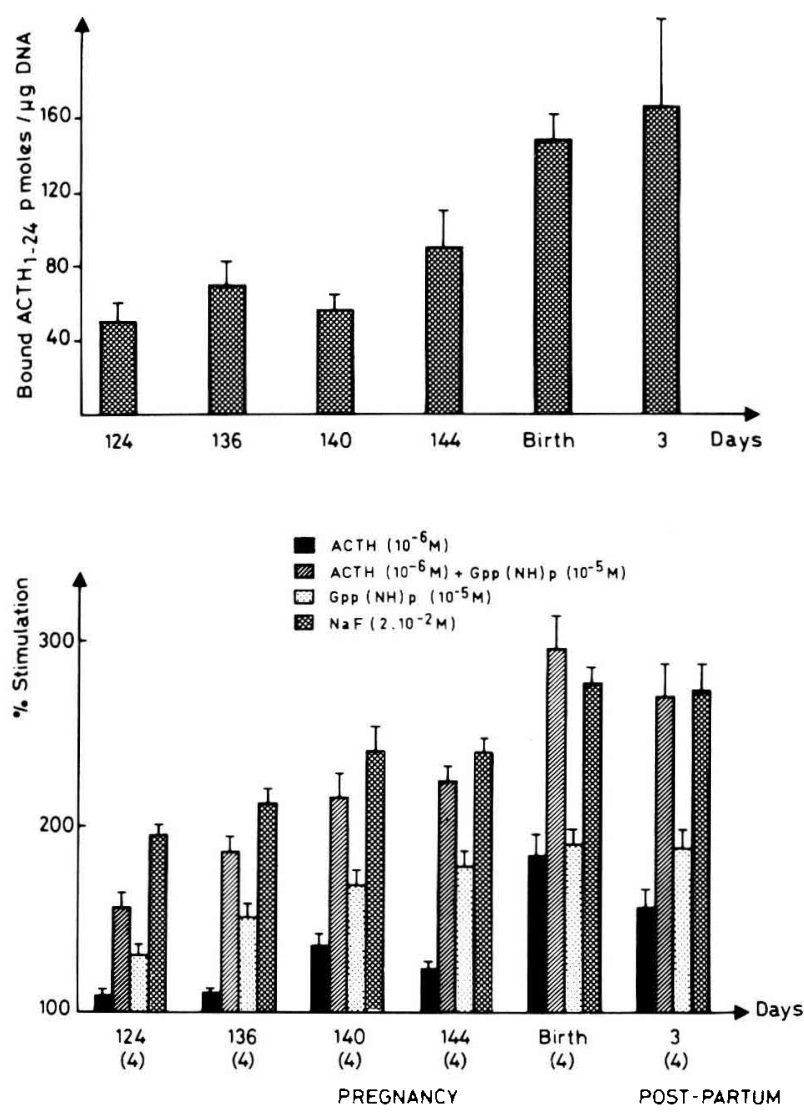

FIG. 1. - ACTH binding (top) and adenylate cyclase (bottom) activities in crude membranes prepared from ovine fetuses at late gestation and from newborn lambs. Results of adenylate cyclase activity are expressed as the percentage of stimulation over basal activity (from Durand et al., 1981b). 
ACTH (1-24) alone cannot increase AC activity, while the addition of a guanosine $5^{\prime}$-triphosphate (GTP) analog to ACTH $(1-24)$ results in a significantly higher response than that observed with $\mathrm{Gpp}(\mathrm{NH}) \mathrm{p}$ alone. However, although there is no increase in the number of $A C T H$ receptors at 140 days, the $A C$ responds to ACTH (1-24) alone. Hence, the relative insensitivity of $A C$ before 140 days of gestation is related primarily to a defect in GTP availability. Secondly, since the response to $\mathrm{Gpp}(\mathrm{NH}) \mathrm{p}$ alone or NaF is lower on day 124 than on day 140, the activity of the catalytic subunit of the cyclase (subunit C) must be lower and/or the guanine nucleotide-binding regulatory components (subunit $\mathrm{Ns}$ and/or $\mathrm{Ni}$ ) altered. Conversely, the increasing responsiveness to ACTH (1-24) observed between day 140 of gestation and birth correlates closely with the concomitant increase in the number of $\mathrm{ACTH}$ receptors since during this period the response to both Gpp $(\mathrm{NH}) \mathrm{p}$ and $\mathrm{NaF}$ remains unchanged. In order to determine which subunit (s) of the $A C$ system was responsible for the enhancement of the response to $\mathrm{Gpp}(\mathrm{NH}) \mathrm{p}$ or NaF, we recently carried out " reconstitution " experiments (Durand et al., $1985 \mathrm{~b})$. In these experiments, human erythrocyte membranes were used as a source of Ns (Johnson et al., 1978). The possible involvement of a Ni subunit was investigated by studying the effects of high GTP concentrations on both the basal and forskolin-stimulated $A C$ activity of fetal and neonatal membranes. The addition of erythrocyte ghosts to fetal adrenal membranes enhanced NaF or Gpp (NH)p stimulation of AC which became similar to that observed in neonate membranes. On the other hand, $A C$ activity displayed a biphasic response to GTP, and the magnitude of the inhibition achieved with $10^{-3} \mathrm{M}$ GTP was similar in fetal and neonatal adrenal membranes. These data show that the " maturation" of the AC system of the ovine fetal adrenal gland involves enhancement of the number of ACTH receptors and development of the Ns subunit, whereas the $\mathrm{Ni}$ and $\mathrm{C}$ subunits are hardly, if at all, involved in this process. Figure 2 shows the in vitro production of cAMP and corticosteroids by
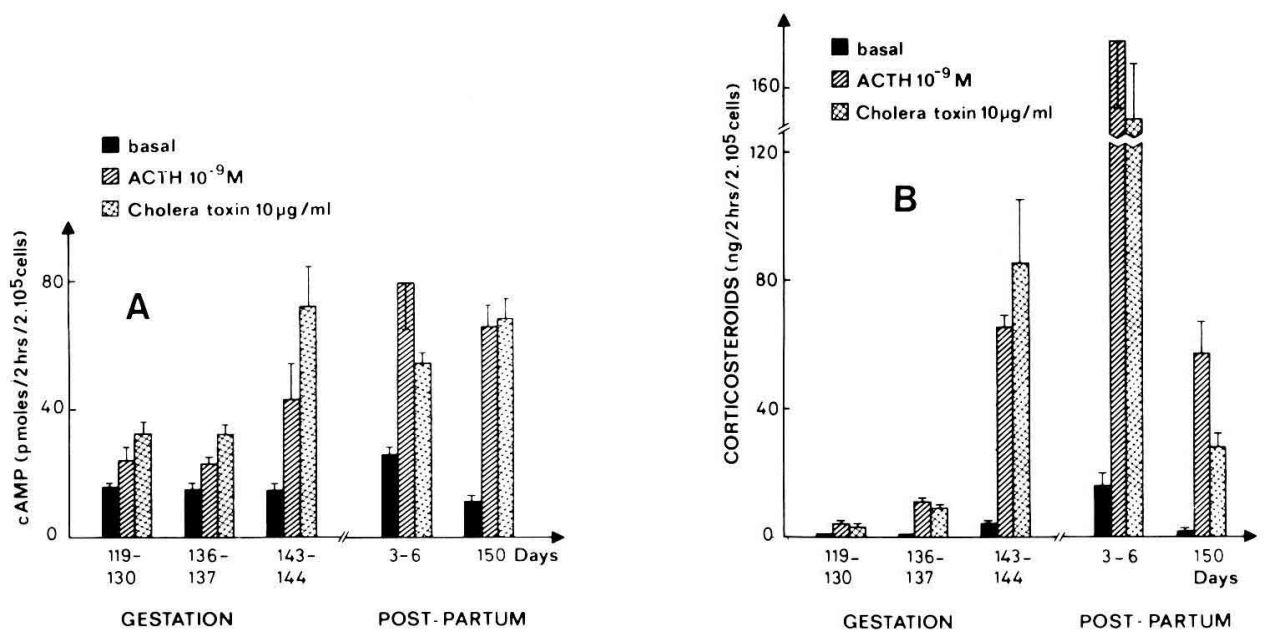

FIG. 2. - Effect of ACTH-(1-24) $\left(10^{-9}\right)$ or cholera toxin $(10 \mu \mathrm{g} / \mathrm{ml})$ on CAMP (A) and corticosteroid $(B)$ production by adrenal cells from fetal, neonatal and adult sheep (from Durand et al., 1981 a). 
isolated adrenal cells from ovine fetuses and lambs. The cAMP response to ACTH $(1-24)$ remains low until 137 days of gestation then increases to reach a peak in newborn lambs. Response to cholera toxin is also developed during the same period, but in that case, maximal stimulation was already obtained in prepartum animals. It can be concluded from the preceding results that the relative unresponsiveness of the fetal adrenal to the steroidogenic effect of ACTH is at least partly related to a defect in the amount of ACTH-induced CAMP production. Such a conclusion has received support from Manchester and Challis (1982) who observed that cAMP, but neither $\mathrm{Gpp}(\mathrm{NH}) \mathrm{p}$ nor $\mathrm{ACTH}$, could stimulate progesterone production by adrenal celis from 130-day old ovine fetuses, whereas those three factors were equipotent with cells from term animals. However, figure 2 shows that the increasing stimulation of steroidogenesis by both ACTH (1-24) and cholera toxin, which occurred between 119-130 and 136-137 days of gestation, was achieved without any detectable change in cAMP output. Also, cholera toxin at 143 days fully stimulated a response in CAMP but not in steroidogenesis. Therefore, modifications beyond cAMP must be involved in the maturation process.

\section{Modification of the steroidogenic pathway}

The in vitro metabolism of labelled pregnenolone by isolated adrenal cells from 120-day old ovine fetuses and from newborn lambs is shown in figure 3. Newborn cells metabolize pregnenolone more rapidly than fetal cells. Moreover, at the end of the incubation period, $80 \%$ of the pregnenolone used by fetal cells

- FETUS

NEWBORN

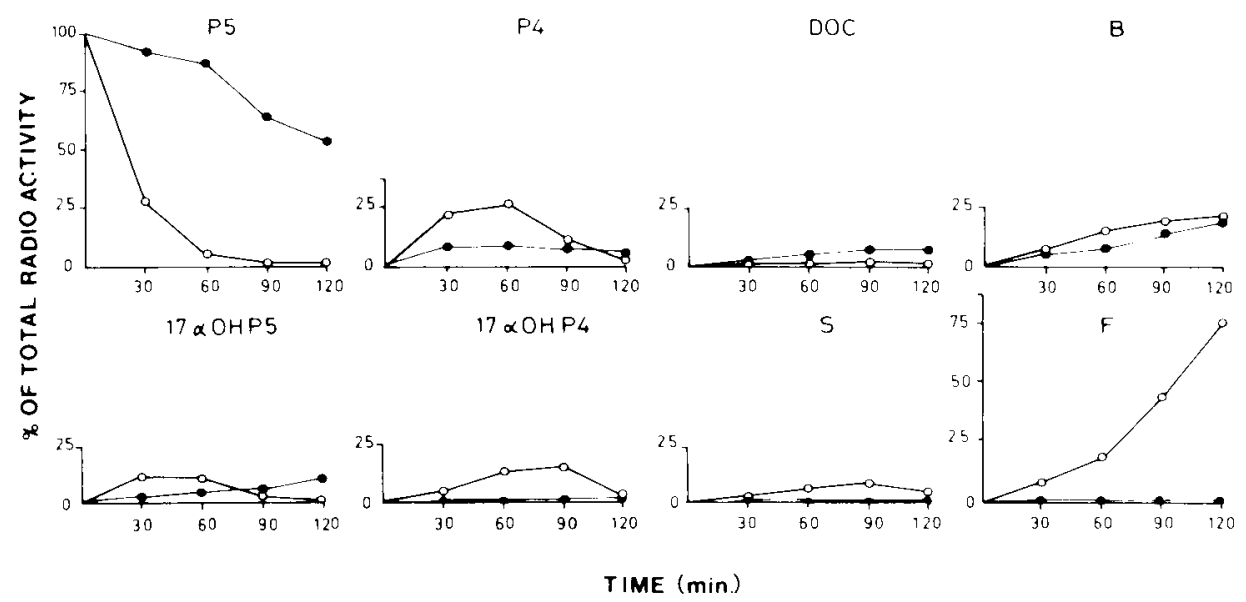

FIG. 3. - Time-course of $\left({ }^{14} \mathrm{C}\right)$-pregnenolone $\left(5 \cdot 10^{-5} \mathrm{M}\right)$ metabolism by adrenal cells isolated from 120-day-old fetuses $(\bullet)$ and 3-day-old newborn lambs $(O)$ (from Durand et al., 1982a). 
was metabolized through the 17-deoxy pathway while the 17-oxy pathway was preferentially used by newborn cells. These results demonstrate deficient $17 \alpha-$ hydroxylase activity in fetal cells. In addition, the slow rate of progesterone formation and the accumulation of $17 \alpha$-hydroxypregnenolone by fetal cells demonstrate the lower activity of $3 \beta$-hydroxysteroid dehydrogenase/isomerase in fetal as compared to newborn lambs. Lastly, the accumulation of progesterone and 11-deoxycorticosterone suggests a partial deficiency of 21-hydroxylase and $11 \beta$-hydroxylase activities in fetal cells. It should be noted that the amount of cortisol plus corticosterone produced under maximal ACTH (1-24) stimulation is always several times lower than that formed in the presence of exogenous pregnenolone, but that the difference is much more pronounced for fetal than for newborn adrenal cells (Durand et al., 1982a, 1984a ; Cathiard et al., 1985a). Hence, it can be concluded that a defect in pregnenolone availability is another very important factor causing fetal adrenal cells to produce less corticosteroid than newborn cells.

\section{Effect of in vivo ACTH (1-24) treatment on the ACTH-receptor adenylate cyclase system.}

The infusion of 115-day old ovine fetuses with $0.1 \mathrm{mg}$ of ACTH (1-24) per day for 5 days resulted in a striking increase in the number of ACTH receptors (fig. 4), and the responsiveness of $A C$ to $A C T H(1-24), G p p(N H) p$ or NaF, higher in ACTH (1-24)-treated fetuses than in control twin fetuses, was similar to that of newborns. Also the responsiveness of adrenal cells isolated from ACTH (1-24)-

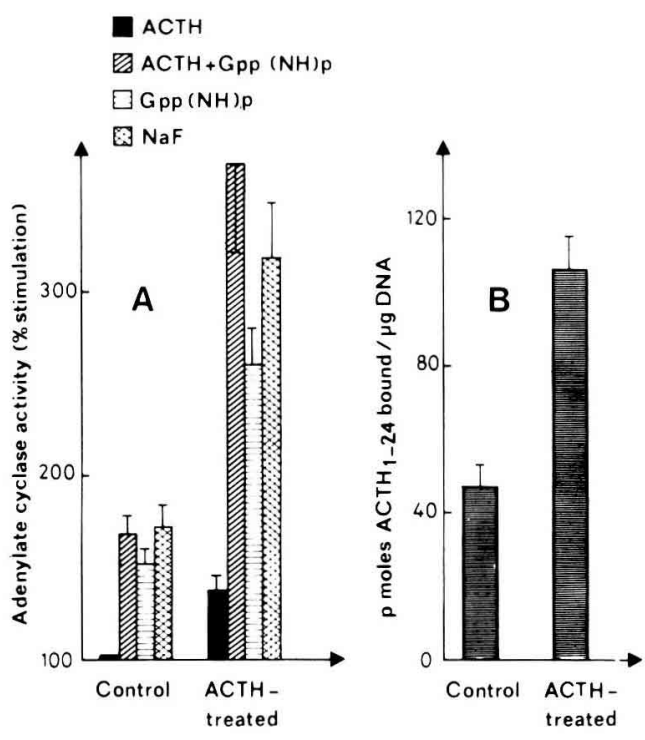

FIG. 4, - Adenylate cyclase (a) and ACTH binding (b) activities of crude adrenal membranes from 120-day-old twin fetuses, one of which had been perfused for five days with ACTH $10.1 \mathrm{mg} /$ day) (from Durand et al., 1981c). 
treated fetuses to in vitro stimulation by ACTH (1-24) or cholera toxin was significantly greater than that of cells from control fetuses in terms of both cAMP and corticosteroid production (Durand et al., 1981c).

\section{Effect of in vivo ACTH (1-24) treatment on the steroidogenic pathway.}

The results presented in figure 5 show that in vivo ACTH (1-24) treatment of fetuses greatly enhanced the rate of in vitro metabolism of ${ }^{14} \mathrm{C}$-pregnenolone

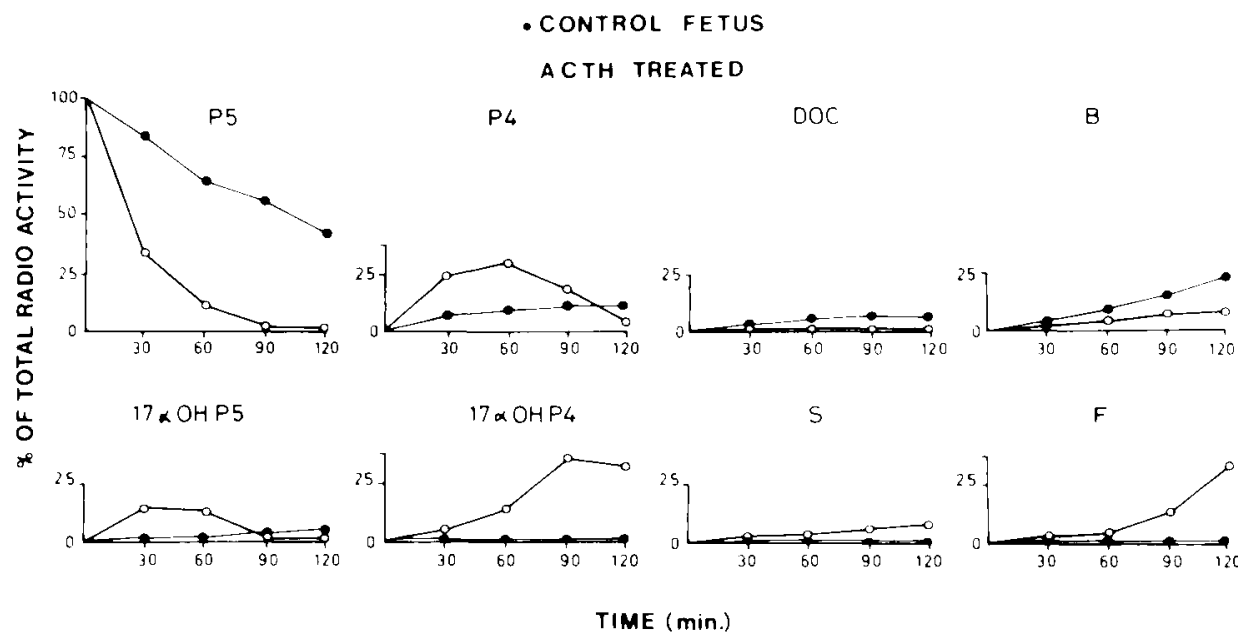

FIG. 5. - Time-course of $\left({ }^{14} \mathrm{C}\right)$ pregnenolone metabolism by adrenal cells isolated from 120-day-old control $(\bullet)$ and ACTH-treated fetuses $(O)$ (from Durand et al., 1982a).

which became similar to that of newborn animals. Moreover, cells from ACTH (124)-treated fetuses preferentially used the 17-oxy pathway as opposed to the control animals. However, there was a progressive accumulation of both $17 \alpha-$ hydroxyprogesterone and, to a lesser extent, of 11-deoxy cortisol in cells from ACTH (1-24)-infused fetuses. These data suggest that 21 and $11 \beta$ hydroxylations are the main rate-limiting steps in ACTH (1-24)-treated fetuses and not $3 \beta$ hydroxysteroid dehydrogenase/isomerase and $17 \alpha$-hydrolase as in control fetuses. It should also be noted that the difference between the amounts of cortisol and corticosterone produced under maximal ACTH (1-24) stimulation or in the presence of exogenous pregnenolone was much less with cells from ACTH (1-24)treated fetuses than with cells from control fetuses (Durand et al., 1982a). It is therefore very likely that ACTH (1-24) treatment enhances pregnenolone synthesis to about the same extent as in newborn lambs.

\section{In vitro development of the ACTH-sensitive adenylate cyclase system.}

Adrenal cells from fetuses were cultured for 6 days in the absence or presence of ACTH $(1-24)\left(10^{-8} \mathrm{M}\right)$. Basal cAMP output remained fairly constant 
throughout the experiment (fig. 6). However, the response to ACTH (1-24) of cells cultured in the absence of this hormone for 5 days was about 25-fold higher on day 6 than on day 1 . When cells were exposed to ACTH (1-24) for $2 \mathrm{~h}$ per day from day 1 onwards, the response to this hormone increased in a striking way during the course of the experiment and CAMP production on day 6 was almost

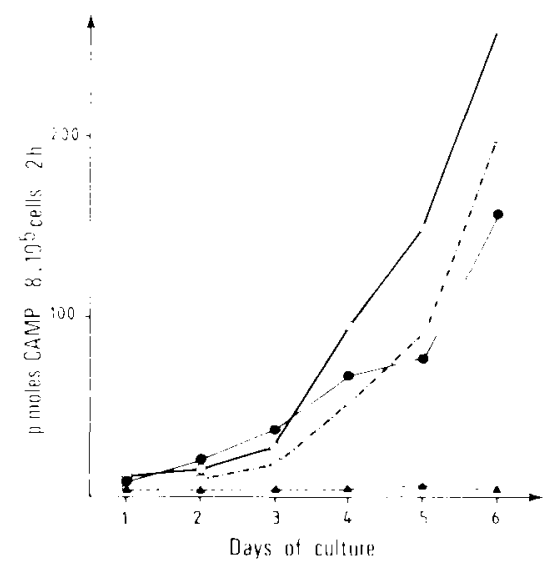

FIG. 6. - cAMP production by cultured adrenal cells from 120-day-old fetuses. Cells were cultured in the absence $(\boldsymbol{\Delta},[])$ or presence of $A C T H-(1-24)\left(10^{-8} \mathrm{M}\right)$ either 24 hrs $(\bullet)$ or 2 hrs $(O)$ per day. Basal

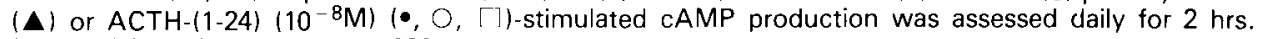
(adapted from Durand et al., 1982c).

40-fold higher than that observed on day 1. However, after 4 days, continous ACTH (1-24) treatment resulted in an acute response to ACTH (1-24) which was weaker than for cells treated only $2 \mathrm{~h}$ per day. Hence, the development observed seemed to involve a combination of at least three processes :

I) increased cAMP response to ACTH (1-24) when cells were cultured in the absence of this hormone for several days :

II) ACTH (1-24)-induced acceleration of CAMP production when ACTH (1-24) was given $2 \mathrm{~h}$ per day;

III) desensitization to ACTH (1-24) when the hormone was continuously present in the culture medium.

The exact causes of the increased responsiveness of $A C$ in vitro are unknown. However, the preliminary results presented in table 1 show that the response to $\mathrm{ACTH}+\mathrm{Gpp}(\mathrm{NH}) \mathrm{p}, \mathrm{Gpp}(\mathrm{NH}) \mathrm{p}$ or NaF of membranes prepared from cells maintained for 6 days in ACTH-free media was much higher than that of cells cultured for only $24 \mathrm{~h}$, whereas the response to forskolin was less altered. This would indicate modifications of some properties of $\mathrm{Ns}$ and perhaps an increase in the number of ACTH receptors and/or better coupling of the receptor and the $A C$ catalytic subunit. 


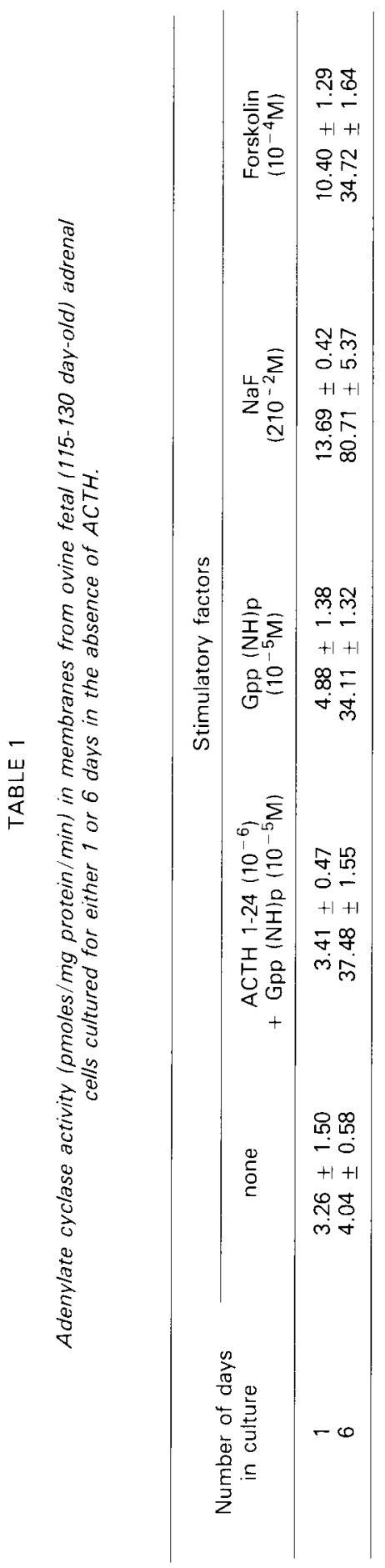




\section{In vitro development of the steroidogenic pathway}

The steroidogenic capacity of fetal adrenal cells maintained in ACTH-free medium increases during culture. Basal and ACTH (1-24)-stimulated corticoid output are respectively 5 and 12 -fold higher on day 6 than on day 1 . The main corticosteroid produced in both cases is corticosterone (Durand et al., 1984a). This increased steroidogenic production is due to an enhancement of pregnenolone production ( 30 -fold) and to a rise (2-fold) in the activity of $3 \beta$ hydroxysteroid dehydrogenase/isomerase (Cathiard et al., 1985a). Continuous ACTH (1-24) treatment from the first day of culture onwards further increases steroidogenic response to the hormone, resulting in a steroid secretion which is more than 110-fold higher on day 6 than on day 1 (Durand et al., 1984a) ; but in this case the main steroid secreted is cortisol. This increase in cortisol production is due not only to a development of $17 \alpha$-hydroxylase activity but also to the enhanced activation of $3 \beta$-hydroxysteroid dehydrogenase/isomerase and 21 hydroxylase. Moreover, pregnenolone production is 110 -fold higher on day 6 than on day 1 (Cathiard et al., 1985a). These results show that the development of $17 \alpha$ and 21-hydroxylase activities are ACTH-dependent, while the development of $3 \beta$ hydroxysteroid dehydrogenase/isomerase and that of some steps involved in pregnenolone biosynthesis are only partially dependent on the hormone. Since even with freshly isolated fetal adrenal cells the enzyme activities involved in the conversion of pregnenolone to corticoids (cortisol plus corticosterone) do not seem to be the major limiting step in the biosynthesis of these steroids (see above), it is likely that the increased ability to produce pregnenolone is the main factor responsible for the enhancement of the capacity of fetal adrenal cells to produce corticosteroids.

All the foregoing data indicate that ACTH is one of the main factors responsible for the maturation of ovine fetal adrenals in late gestation both at the membrane level and at the steroidogenic pathway. In addition, the results of our in vitro experiments suggest that the maturation of ovine fetal adrenal in vivo is blocked by the presence of some inhibitory factors in the fetal circulation. However, data available from most laboratories studying the ovine fetus suggest that the prepartum increase in glucocorticoid secretion occurs prior to any large increase in fetal plasma ACTH levels (Ress et al., 1975; Jones et al., 1977 ; Wintour et al., 1980 ; Hennessy et al., 1982 ; Rose et al., 1982). Hence, it is now of primary importance to determine whether the sharp, prepartum increase in the fetal adrenocortical function involves only ACTH (" automagnifying phenomenon ") or whether it is due to a decrease of the inhibitory factors or even to an increase of some synergistic factors on ACTH action. Recently, several authors have shown that some peptides derived from the $\mathrm{N}$-terminal fraction of POMC could have a biological activity in adrenal steroidogenesis in both adult rats and humans (Pedersen and Brownie, 1980 ; Al Dujaili et al., 1981 ; Lis et al., 1981).

Therefore, we examined the effects of some peptides, derived from the nonACTH part of POMC, and the influence of acid pituitary extracts from fetal or newborn lambs on the in vitro maturation of ovine fetal adrenal cells. In addition, 
we determined the influence of fetal hypophysectomy on the spontaneous and ACTH-induced maturation of cultured fetal adrenal cells.

\section{Effects of POMC-derived peptides and of acid pituitary extracts on the maturation of ovine fetal adrenal cells in culture.}

The following POMC-derived peptides were used : porcine POMC N-terminal (1-80) [N-POMC-(1-80)], amidated porcine POMC N-terminal (1-61) [N-POMC-(161)], porcine $\beta$-LPH, $\gamma 2-\mathrm{MSH}$ and $\gamma 3-\mathrm{MSH}$. We tested the effect of these peptides, alone or in combination with ACTH (1-24), on the development of the ability of adrenal cells from 125-day old ovine fetuses to produce both cAMP and corticosteroids (Durand et al., 1984b). N-POMC-(1-61) amide, $\gamma 2-\mathrm{MSH}$ and $\gamma 3-$ MSH behaved similarly in our system :

1) they slightly increased corticosteroid production without modifying cAMP output when added alone to the incubation medium, but this effect was seen only after 3 days of culture ;

II) they potentiated steroidogenic response to $10^{-11} \mathrm{M} \mathrm{ACTH} \mathrm{(1-24)} \mathrm{but} \mathrm{also} \mathrm{only}$ from day 3 onwards ;

III) a 5-day peptide treatment induced fetal adrenal cell maturation resulting in the same enhancement of the corticosteroid production stimulated by $10^{-8} \mathrm{M} \mathrm{ACTH}$ (1-24) without modifying the response of either CAMP or pregnenolone.

N-POMC (1-80) and $\beta$-LPH shared several common features because : 1) each one alone stimulated corticosteroid production significantly more than was obtained with the other POMC-derived peptides (except ACTH $(1-24)$ ) ; II) they did not potentiate the steroidogenic action of $10^{-11} \mathrm{M} \mathrm{ACTH}(1-24)$; III) when cells were cultured in their presence for 5 days, the response to ACTH (1-24) was enhanced in respect to cAMP and pregnenolone outputs as well as to cortisol + corticosterone production.

In a second series of experiments, we assessed the daily response of cultured adrenal cells repeatedly stimulated by either ACTH (1-24) or by acid pituitary extracts from 124-day old fetuses or 5-day old newborns and observed that both CAMP and corticosteroid outputs induced by ACTH (1-24) or by fetal or newborn pituitary extracts developed identically to become 7 and 40 -fold higher, respectively, on day 4 than on day 1 . Moreover the response to $A C T H(1-24)$ on day 5 was also identical in both CAMP and corticosteroids whether the cells had been previously treated with ACTH $(1-24)$ or with fetal or newborn pituitary extracts (Durand et al., 1985a).

The above data show that N-POMC-derived peptides can potentiate the acute steroidogenic activity of $\mathrm{ACTH}(1-24)$ on ovine fetal adrenal cells after several days in culture. They also demonstrate that some of these peptides, including $\beta$-LPH, have a trophic effect which enhances the response of fetal cells to the steroidogenic role of ACTH (1-24). It should be emphasized that such a behaviour appears to be specific to fetal cells since it is not observed in adult cells 
(Cathiard et al., 1985b). Finally, it appears that the pituitary from 124-day old ovine fetuses contains enough trophic (and steroidogenic) substances to allow in vitro adrenal maturation. However, very. little is known of the ability of fetal pituitary cells to release adrenocorticotrophic substance(s) in the fetal circulation under physiological conditions (Durand et al., 1982b).

\section{Effect of fetal hypophysectomy on in vitro maturation of cultured ovine fetal adrenal cells.}

The adrenal cells from 124-day old ovine fetuses (intact or hypophysectomized at 118 days of gestation) were cultured for 6 days in the absence or presence of $10^{-8} \mathrm{M}$ ACTH (1-24). Figure 7 shows that with ACTH (1-24) treatment, cAMP and corticosteroid responses to the hormone developed more slowly in cells from hypophysectomized fetuses than in cells from control fetuses during the first 3 days of culture. Likewise, both cAMP and corticosteroid responses to the ACTH (1-24) of adrenal cells from hypophysectomized fetuses cultured for 1 to 3 days in the absence of ACTH were lower than those of cells from control fetuses cultured under the same conditions (Durand et al., 1985a). At the beginning of culture, adrenal cells from hypophysectomized fetuses also showed lower pregnenolone metabolism than that of cells from intact fetuses. The addition of ACTH (1-24) to the culture medium increased the activity of $3 \beta$-hydroxysteroid dehydrogenase/isomerase, $17 \alpha$ and 21-hydroxylases within 5
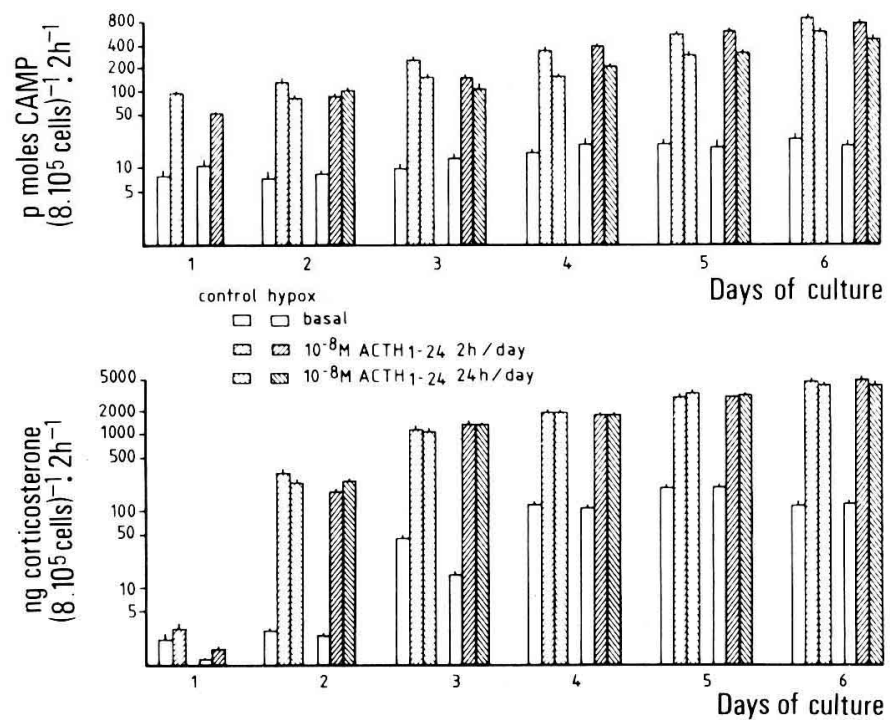

FIG. 7. - cAMP and corticosteroid productions by cultured ovine adrenal cells from 124-day-old control $\square$ and $H \times \square$ ovine fetuses. Cells were cultured in the absence ( $\square, \mathbf{D}$ ) or presence of ACTH 1$24\left(10^{-8} \mathrm{M}\right)$ either for 2 hours $(0,0)$ or 24 hours ( $\mathrm{G}, \mathbb{\mathbb { N }} / \mathrm{day}$. Basal $(\square, \square)$ or $\mathrm{ACTH}(1-24)$ stimulated ( $, 0,0$ ) CAMP and corticosteroid productions were assessed daily for 2 hrs. (from Durand et al., 1985a). 
days, but the activity of $17 \alpha$-hydroxylase in adrenal cells from hypophysectomized fetuses remained lower than that of cells from intact fetuses (Cathiard et al., 1985b). These data demonstrate that removal of pituitary hormones in vivo decreases the ability of fetal adrenal cells to respond in vitro to ACTH (1-24). Moreover, since no development at all occurs in vivo in the absence of the pituitary gland (Durand et al., 1985a), the putative factors inhibiting fetal adrenal maturation may still be present after hypophysectomy.

\section{Conclusion}

The results presented here define some of the biochemical steps involved in the maturation of ovine fetal adrenal cells during late gestation. They also demonstrate that ACTH (1-24) can induce fetal adrenal cells to respond to ACTH in a way similar to that of cells from newborn lambs. Moreover, they suggest that, in addition to $\mathrm{ACTH}$, two kinds of factors are needed for the regulation of this maturation :

I) stimulatory factors, some of which are probably derived from POMC and can act either alone or by potentiating ACTH action ;

II) inhibitory factors of likely extrapituitary origin.

Obviously, there are many gaps in our understanding of this process. For example, at the biochemical level it is now important to determine whether the increased activity of Ns results from a larger number of subunits or a modification of their properties. Another problem is understanding the causes of the lower capacity of fetal adrenal cells to produce pregnenolone as compared to newborn cells. In addition, nothing is known of the development of the steps which allow the hormonal signal to be transmitted from the plasma membrane to the intracellular structures which synthesize corticosteroids.

Finally, it is not clear yet whether the changes observed in vivo result from the progressive appearance in the adrenal gland of cells responsive to ACTH and/or development of the steroidogenic capacity of pre-existing cells. As for the hormonal "coktail » which regulates maturation, it now appears essential to determine the " corticotropic activity " released in the fetal circulation during the last 3 weeks of gestation and to identify the different molecules responsible for that activity. In a second step, the regulation of the secretion of these different hormones will have to be investigated.

Réunion d'Endocrinologie de l'Association des Physiologistes, Clermont, 23-24 Avril 7985.

Acknowledgements. - This work was supported by DGRST grant $N^{\circ} 80.7 .00 .17$ and INSERM grant ATP 71.18.103. 
Résumé. Modifications biochimiques impliquées dans la maturation de la fonction corticosurrénalienne du foetus ovin: modalités et régulation.

Au cours du dernier mois de la vie intra-utérine, la réponse steroidogénique à l'ACTH des glandes surrénales du fœtus ovin augmente, et devient maximale au moment de la naissance. Ce développement traduit des modifications situées à différentes étapes du mécanisme d'action de l'ACTH. Au niveau de la membrane plasmique, nous avons montré que l'augmentation de la production d'AMPc implique au moins trois processus : une augmentation du nombre de récepteurs de I'ACTH, une activité accrue de la sous-unité Ns de l'adénylate cyclase, une augmentation du GTP disponible. Au niveau de la chaîne de biosynthèse des corsticosteroides, on observe principalement un accroissement de la capacité de synthèse de la pregnénolone, et des activités augmentées pour les $3 \beta$ hydroxystéroide déshydrogénase/isomérase et $17 \alpha$-hydroxylase. Une infusion d'ACTH de 5 jours à des fœtus agés de 115-120 jours est capable d'induire la plupart de ces modifications. De même, l'ACTH peut induire la maturation des cellules surrénaliennes fœtales en culture, et certains peptides dérivés de la POMC potentialisent son effet steroidogénique aigu in vitro. Cependant, même en absence d'ACTH, le système adénylate cyclasique et les potentialités steroidogéniques des cellules en culture se développent, mais à un degré moindre que lorsque l'ACTH est présente dans le milieu de culture. Ces résultats suggèrent que I'ACTH est la principale hormone trophique de la surrénale fœtale ovine au cours du dernier mois de la gestation, même si d'autres facteurs stimulants sont également requis. La maturation surrénalienne fotale est bloquée in vivo par la présence dans la circulation fœtale de facteurs inhibiteurs dont l'origine est vraisemblablement extra hypophysaire.

\section{References}

AL DUJAILI E. A. S., HOPE J., ESTIVARIZ F. E., LOWRY J. P., EDWARDS C. R. W., 1981. Circulating human pituitary pro- $\gamma$-melanotropin enhances the adrenal responses to ACTH. Nature, 291, 156-159.

BASSETT J. M., THORBURN G. B., 1973. Circulating levels of progesterone and corticosteroids in the pregnant ewe and its fœtus, 126-140. In : PIERREPOINT C. G., Endocrinology of pregnancy and parturition Experimental studies in the sheep. Alpha omega alpha, Cardiff.

CATHIARD A. M., CROZAT A., DURAND Ph., SAEZ J. M., 1985a. In vitro spontaneous and ACTH-dependent maturation of the steroidogenic pathway of ovine fetal adrenal cells. Endocrinology, 116, 585-590.

CATHIARD A. M., DURAND Ph., SEIDAH N. G., CHRETIEN M., SAEZ J. M., 1985b. Effects of several POMC-derived peptides on steroidogenesis in ovine and bovine adrenal cells. $J$. Steroid. Biochem. (in press).

COMLINE R. S., SILVER M., 1961. The release of adrenaline and noradrenaline from the adrenal glands of the foetal sheep. J. Physiol. Lond., 156, 424-444.

DURAND Ph., BOSC M., NICOLLE A., 1978. Croissance des surrénales du fœtus ovin en fin de gestation : évolution de l'ADN et des proteines membranaires. C. R. Acad. Sci. Paris. Ser. D, 287, 297-300.

DURAND Ph., CATHIARD A. M., LOCATELlI A., DAZORD A., SAEZ J. M., 1981a. Spontaneous and $A C T H$-induced maturation of the responsiveness of ovine fetal adrenal cells to " in vitro " stimulation by ACTH and cholera toxin. Endocrinology, 109, 2117-2123.

DURAND Ph., CATHIARD A. M., LOCATELLI A., SAEZ J. M., 1982a. Modification of the steroidogenic pathway during spontaneous and $A C T H$-induced maturation of ovine fetal adrenal. Endocrinology, 110, 500-505.

DURAND Ph., CATHIARD A. M., LOCATELLI A., SAEZ J. M., 1982b. Ontogenèse de la fonction corticosurrenalienne dans l'espèce ovine, 189-218. In SAEZ J. M., BERTRAND J., DUCHARME J. R., COLLU R., Ontogenèse du système endocrinien, Ed. INSERM. Paris, vol. 109. 
DURAND Ph., CATHIARD A. M., LOCATELLI A., SAEZ J. M., 1985a. Effects of fetal hypophysectomy and the in vitro treatment by pituitary extracts on the maturation of cultured ovine fetal adrenal cells. Endocrinology, 116, 578-584.

DURAND Ph., CATHIARD A. M., MORERA A. M., DAZORD A., SAEZ J. M. 1981b. Maturation of ACTH-sensitive adenylate cyclase of ovine fetal adrenal during late pregnancy. Endocrinology, 108, 2114-2119.

DURAND Ph., CATHIARD A. M., SAEZ J. M., 1982c. In vitro maturation of ovine fetal adrenal cells adenylate cyclase : ACTH-dependent and independent development of the response to ACTH. Biochem. Biophys. Res. Commun., 106, 8-15.

DURAND Ph., CATHIARD A. M., SAEZ J. M., 1984a. In vitro maturation of steroidogenic capacity of ovine fetal and neonatal adrenal cells. Endocrinology, 114, 1128-1134.

DURAND Ph., CATHIARD A. M., SAEZ J. M., 1985b. Involvement of the regulatory protein (Ns) in the maturation of ACTH-sensitive adenylate cyclase of ovine fetal adrenal during late gestation. Mol. cell. Endocr., 39, 145-150.

DURAND Ph., CATHIARD A. M., SEIDAH N. G., CHRETIEN M., SAEZ J. M., 1984b. Effects of POMC-derived peptides, methionine-enkephalin and forskolin on the maturation of ovine fetal adrenal cells in culture. Biol. Reprod., 31, 694-704.

DURAND Ph., LOCATELLI A., CATHIARD A. M., DAZORD A., SAEZ J. M., 1981c. ACTH induction of the maturation of $A C T H$-sensitive adenylate cyclase system in the ovine fetal adrenal. J. Steroid Biochem., 15, 445-448.

HENNESSY D. P., COGHLAN J. P., HARDY K. J., WINTOUR E. M., 1982. Development of the pituitary-adrenal axis in chronically cannulated ovine fetuses. J. develop. Physiol., 4, 339-352.

JOHNSON G. L., KASLOW H. R., BOURNE H. R., 1978. Reconstitution of cholera toxin-activated adenylate cyclase. Proc. nat. Acad. Sci, U.S.A., 75, 3113-3117.

JONES C. T., BODY K., ROBINSON J. S., 1977. Changes in the concentration of ACTH and corticosteroid in the plasma of foetal sheep in the latter half of pregnancy and during labour. J. Endocr., 72, 293-300.

LIGGINGS G. C., 1968. Premature parturition after infusion of corticotrophin or cortisol into foetal lambs. J. Endocrinol., 42, 323-329.

LIS M., HAMET P., GUTOWSKA J., MAURICE G., SEIDAH N., LARIVIERE N., CHRETIEN M., GENEST J., 1981. Effect of $\mathrm{N}$-terminal portion of POMC on aldosterone release by human adrenal adenoma in vitro. J. clin. Endocr. Metab., 52, 1053-1056.

MADILL D., BASSET J. M., 1973. Corticosteroid release by adrenal tissue from foetal and newborn lambs in response to corticotrophin stimulations in a perfusion system in vitro. J. Endocr., 58, 75-87.

MANCHESTER L., CHALLIS J. R. G., 1982. The effect of ACTH, guanylylimido-diphosphate, dibutyryl adenosine $3^{\prime}, 5^{\prime}$ monophosphate, and exogenous substrates on corticosteroid output by ovine fetal adrenal cells at different times in pregnancy. Endocrinology, 111, 889895.

PEDERSEN R. C., BROWNIE A. C., 1980. Adrenocortical response to ACTH is potentiated by part of the amino-terminal region of pro-opiocorticotrophin/endorphin. Proc. nat. Acad. Sci. U.S.A., 77, 2239-2243.

REES L. H., JACK P. M. B., THOMAS A. L., NATHANIELSZ P. W., 1975. Role of foetal ACTH during parturition in sheep. Nature, 253, 274-275.

ROBINSON P. M., ROWE E. J., WINTOUR E. M., 1979. The histogenesis of the adrenal cortex in the foetal sheep. Acta endocr. (Copenh.), 91, 134-149.

ROSE J. C., MEIS P. J., URBAN R. B., GREIS Jr F. C., 1982. In vivo evidence for increased adrenal sensitivity to ACTH 1-24 in the lamb fetus late in gestation. Endocrinology, 111, 80-85.

WINTOUR E. M., BROWN E. H., DENTON D. A., HARDY K. J., Mc DOUGALL J. G., ODDIE C. J., WHIPP G. T., 1975. The ontogeny and regulation of corticosteroid secretion by the ovine foetal adrenal. Acta endocr. (Copenh.), 79, 301-316.

WINTOUR E. M., GOGHLAN J. P., HARDY K. J., HENNESSY D. P., LINGWOOD B. E., SCOGGINS B. A., 1980. Adrenal corticosteroids and immunoreactive ACTH in chronically cannulated ovine fetuses with bilateral adrenalectomy. Acta endocr. (kbh), 95, 546-552. 